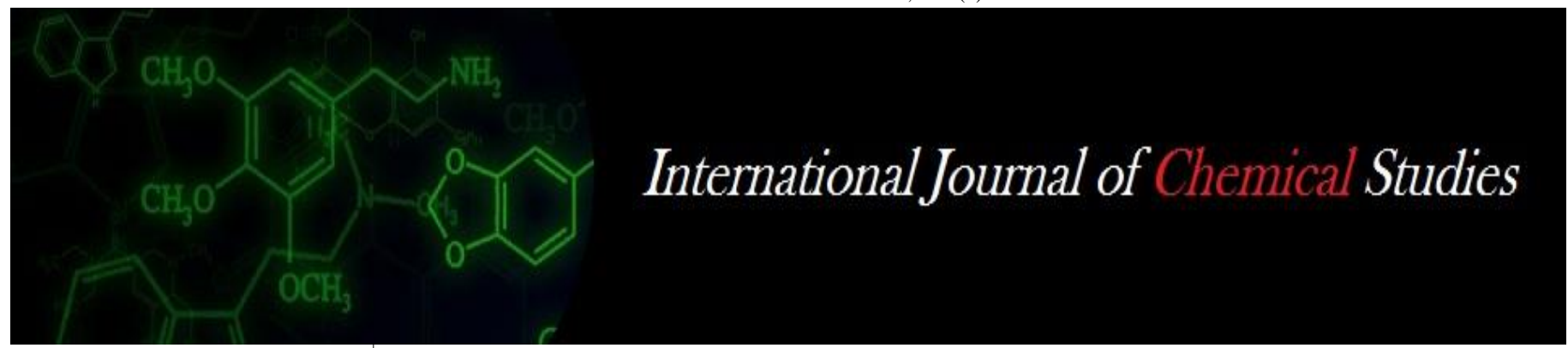

P-ISSN: 2349-8528

E-ISSN: 2321-4902

www.chemijournal.com

IJCS 2020; SP-8(5): 202-210

(C) 2020 IJCS

Received: 25-07-2020

Accepted: 29-08-2020

\section{Jyotsana Pandit}

Department of Environmenta

Science, University of

Horticulture and Forestry,

Nauni, Solan, Himachal

Pradesh, India

\section{SK Bhardwaj}

Department of Environmental

Science, University of

Horticulture and Forestry,

Nauni, Solan, Himachal

Pradesh, India

\section{Quantification, characterization and footprint appraisal of solid waste in urban areas of Solan district in Himachal Pradesh}

\author{
Jyotsana Pandit and SK Bhardwaj
}

DOI: https://doi.org/10.22271/chemi.2020.v8.i5d.10607

\begin{abstract}
As the world hurtles towards its urban future, the amount of solid waste, one of the most important by products of an urban lifestyle, is growing even faster than the rate of urbanization. The paper presents the quantification, characterization and footprint assessment of solid waste in urban areas of Solan District. The study reported that the total quantity of urban solid waste generated varied from 0.896 to $19.527 \mathrm{t}$ day $^{-1}$. Organics, paper, plastic, glass, others, metal, textiles, rubber / leather wastes represented $50.01 \%$, $21.93 \%, 18.42 \%, 4.25 \%, 2.10 \%, 1.20 \%, 1.09 \%$ and $1.00 \%$ consequently. Per capita waste generation rates ranged from 0.217 to $0.408 \mathrm{~kg} \mathrm{capita}^{-1} \mathrm{day}^{-1}$. The waste footprint of different urban areas varied from 0.002 to 0.035 ha. Thus the results revealed that the majority of waste was organic $(50.01 \%)$, suggesting a strong resource recovery potential in terms of animal feed or compost. Waste separation should be enforced at the source level, which could promote reuse and recycling, leading to maximum recovery potential and reduced waste volumes.
\end{abstract}

Keywords: Urban solid waste, quantification, characterization, projections, waste footprint

\section{Introduction}

Solid waste generation has become an issue of concern everywhere in the world, in metropolitan focuses particularly in tourist areas. It is influenced by economic conditions, living standards and population the fast economic development and urbanization, the generation of solid waste has quickly expanded worldwide and the composition of waste has additionally changed altogether. These changes bring more pressure on the existing environment, human wellbeing and furthermore to the waste administration framework (USEPA, 2002) ${ }^{[1]}$. For the most part, expanded populace development and rising consumer choices have resulted in a larger production of waste worldwide with varied composition (Karak et al., 2012) ${ }^{[2]}$. The characteristics and composition of solid waste depends on the topography of the area, seasons, food propensities and commercial status of the area, should be characterized for source, generation rates, type of wastes produced and composition, in order to monitor, control and to improve prevailing waste management systems (Palanivel and Sulaiman, 2014) ${ }^{[3]}$. Globally, the waste generation rate has increased ten times since the last century and is probably going to double by 2025 (Hoornweg et al., 2013) ${ }^{[4]}$. Urban solid waste is defined as local waste generated by households and commercial and governmental enterprises. It includes packaging, food waste, grass clippings, clothing, paper and other solid forms of waste, but does not include hazardous and infectious waste or sewage (Solberg, 2012) ${ }^{[5]}$. A few examinations show that a great part of urban solid waste from developing countries are generated from households $(55-80 \%)$, followed by commercial or market areas (10-30\%) with varying quantities from streets, industries, institutions among others (Nabegu, 2010) ${ }^{66]}$. Waste from these sources are highly heterogeneous in nature (Valkenburg et al., 2008) ${ }^{[7]}$ and have variable physical attributes relying on their sources; notably in their composition which would be difficult to classify. The heterogeneity of the generated waste is a significant difficulty in its usage as a crude material. There is subsequently the requirement for fractionation of the waste before they can be subjected to any important treatment process.

There is a general consensus in the literature that household solid waste generation is straightforwardly connected to a region's financial markers. Growing cities and cities enjoying
Corresponding Author: Jyotsana Pandit Department of Environmenta Science, University of Horticulture and Forestry, Nauni, Solan, Himachal Pradesh, India 
positive socio-economic indicators should pay attention to household solid waste generation and management as a way of reducing waste-related environmental hazards (Yukalang et al., 2018) ${ }^{[8]}$. The formation rate and composition of urban solid waste are influenced by numerous factors such as the season, kitchen habits, collection frequency, economic conditions, recycle culture and the ability to reuse and regional cultures (Delgado et al., 2015) ${ }^{[9]}$. Moreover, the monetary status of the country is especially effective in changing the waste amount and composition. In India, the per capita generation of solid waste varies from $0.15 \mathrm{~kg}$ in rural locations to $0.45 \mathrm{~kg}$ in urban areas (Khaiwal et al., 2015) ${ }^{[10]}$. It is getting progressively costly for city specialists over the globe to oversee solid waste in ways that are environmentally friendly and defensive to human wellbeing (Gutberlet, 2018) [11]. An absence of appropriate waste administration frameworks brings about wild littering as huge amounts of waste end up heedlessly discarded, presenting dangers to human wellbeing and nature (Okot-Okumu, 2012) ${ }^{[12]}$. Waste is dumped on land in an uncontrolled manner, and in most cities openly burning waste, illicit dumping and sending huge volumes of waste to landfill locales are regular practices (Mohammed and Elias, 2017) ${ }^{[13]}$. Waste is dumped in the streets and in drains, subsequently adding to flooding, the breeding of insect and rodent vectors, the spread of diseases and the uncontrolled release of methane by anaerobic decay of waste. Solid waste that has been inappropriately discarded is a major source of greenhouse gases that intensify global warming (Yadav, 2018) ${ }^{[14]}$ and is generated faster than any other environmental pollutants (Thanh et al., 2010) ${ }^{[15]}$.

As waste generation rates across the globe continue to show an increasing trend, waste management authorities, especially in most countries' fast-growing cities, are bound to fail to account for solid waste service function and to provide effective solid waste systems. There is a concern that the mismanagement of household solid waste may be a significant risk factor for environmental degradation. The inefficiency of most growing cities' waste management systems can be partly attributed to insufficient information on waste production, handling and sorting in developing countries, which is difficult to obtain, given the lack of records and often-informal nature of waste management and disposal (Aslani and Taghipour, 2018) ${ }^{[16]}$. In developed countries, urban solid waste is usually well managed. Often the highly technical and complicated methods of dealing with MSW used effectively in developed countries are brought to developing countries. However, these solutions are often not sustainable due to lack of capacity and the incongruity of trying to establish systems in dissimilar situations (Marshall and Farahbakhsh, 2013) ${ }^{[17]}$. Urban solid waste management in

developing countries accounts for between $20 \%$ and $50 \%$ of local government budgets (Schubeler P, 1996) ${ }^{[18]}$. One of the most significant issues in protecting the environment and natural sources is waste management. Therefore, sorting of the solid wastes at the source, collecting, transferring, processing, recycling and disposal of the wastes are among the important environmental issues in today's world (Mir et al., 2016) ${ }^{[19] .}$

In earlier days, urban solid wastes, comprised mainly of biodegradable matter, did not create much problem to the community as the quantity of wastes generated was either recycled/reused directly as manure or was within the assimilative capacity of the local environment (Puthillath and Sasikumar (2015) ${ }^{[20]}$. With increasing content of plastics and non-biodegradable packaging materials, excessive accumulation of solid wastes in the urban environment poses serious threat not only to the urban areas but also to the rural areas. Now, dealing with waste, is a major challenge in many of the local bodies or government. Though there are campaigns and awareness programmes to reduce the waste generation and source reduction, it is very hard to maintain the enthusiasm after the campaigns. In these circumstances we have to think of an alternative which is to be enforced by laws or rewards to reduce the amount of waste generation. A system, which gives the waste impact on earth quantified, just as we take the current bill, water bill etc and an amount to be paid based on the quantity, should be imagined. Or on the other hand the waste generators which are causing low impact should be rewarded or appreciated. There should be clear cut limit for this quantified value based on the locality we live in and its biocapacity to assimilate the waste. Waste foot printing is one such tool which can reach these goals to some extent (Varma, 2015) ${ }^{[21]}$. Waste foot print or ecological footprint of waste generation is the measurement of biologically productive land required to assimilate the generated waste (Wackernagel et al., 2006) ${ }^{[22]}$. It provides per capita land requirements for waste generation (Salequzzaman et al., 2006) ${ }^{[23]}$. By its calculation the local authority can determine the land required assimilating the waste generated in present and future, selection of disposal site and disposal site characteristics, the land fill site design and the importance of recycling of different waste categories in order to reduce the footprint (Ravi et al., 2017) ${ }^{\text {[24]. }}$ Therefore present study aimed at solid waste characterization and footprint assessment of urban areas of Solan District.

\section{Material and Methods \\ Study area}

The present study was conducted during 2018 and 2019 in the Solan District lying between North latitude of $30^{\circ} 44^{\prime} 53^{\prime \prime}$ to $31^{\circ} 22^{\prime} 01^{\prime \prime}$ and East longitude of $76^{\circ} 36^{\prime} 10^{\prime \prime}$ to $77^{\circ} 15^{\prime} 14^{\prime \prime}$ of Himachal Pradesh. The climate of the district is sub-tropical to sub-temperate type and experience four seasons during the year. The spring season commences from March to April and end in May, summer season falls from June to August, followed by autumn which falls from September to November and winter from December to February. In this region $70 \%$ of rains are received during monsoon months i.e. from June to September). The average annual rainfall in the district is about $1140 \mathrm{~mm}$. The average minimum and maximum temperature ranges from $4{ }^{\circ} \mathrm{C}$ and $40{ }^{\circ} \mathrm{C}$. In order to assess the surface water quality in Solan district five urban areas viz., Arki, Baddi, Parwanoo, Nalagarh and Solan were selected (Fig.1) 


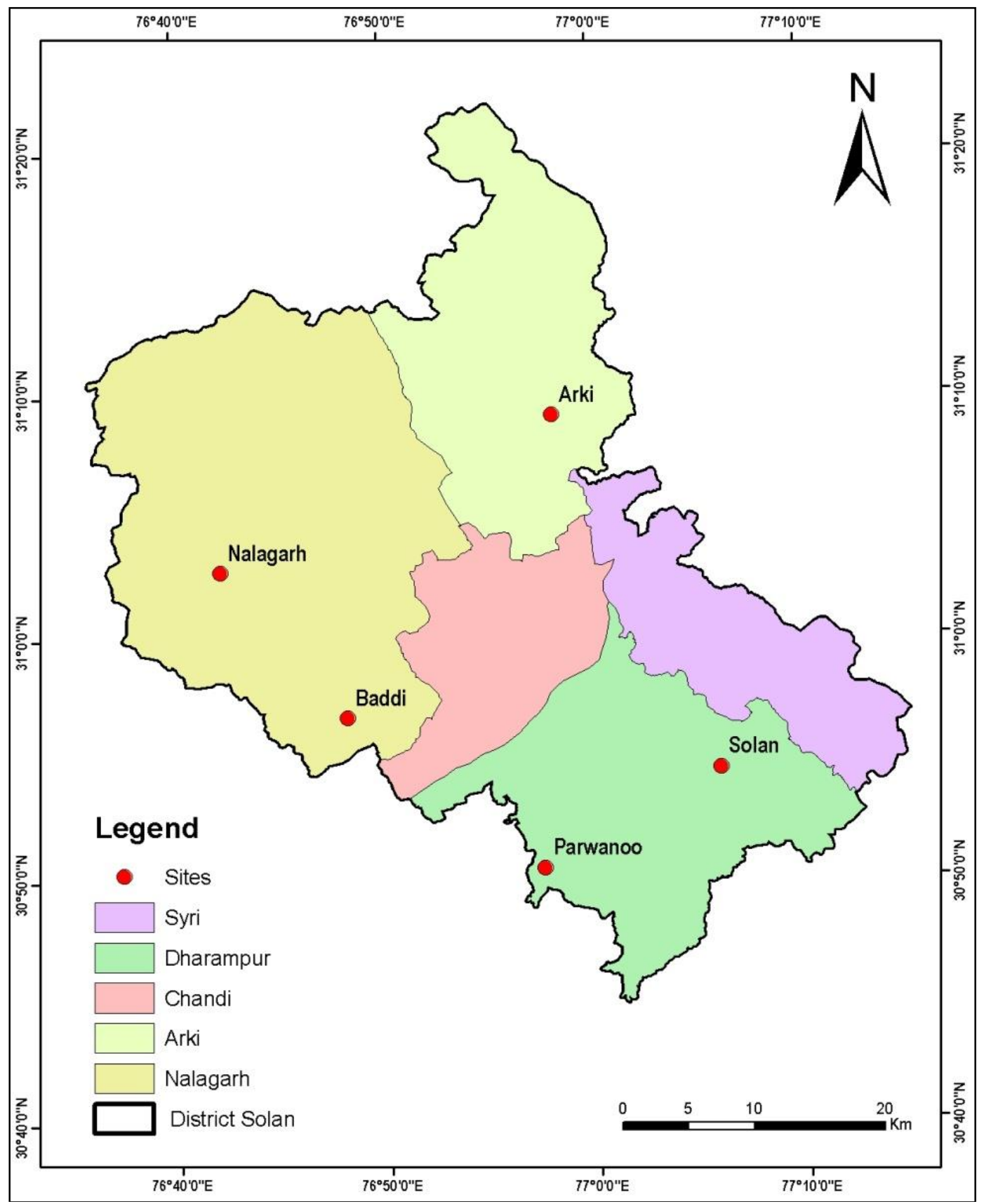

Fig 1: Location Map of study area

\section{Quantification and characterization of urban solid waste}

The survey was conducted in the study area to gather basic information, assess working conditions and to gauge the current status of solid waste management. Based on the survey, ten percent sample was taken from each site (residential, commercial and institutional). Samples were collected from different sites by stratified random sampling method. To balance out the daily and seasonal variations sampling was carried out for one week for each season. Quantification of waste for each site was done at generation sources on wet weight basis. Scientific balance with a capacity of five $\mathrm{kg}$ (for residential building) and $100 \mathrm{~kg}$ (for commercial) was used to determine the actual quantity of waste generated at different generation sources. In order to estimate the total quantity of waste generated the data regarding total number of residential, commercial and institutional establishments in different urban areas was collected from the official certified records maintained by Municipal Councils of Baddi, Nalagarh, Parwanoo, Solan and
Arki Nagar Panchayat as well as Himachal Pradesh Government website and their detail is referenced.

After estimation of total waste generated separately for each site, physical sorting was done manually to separate out different components. The segregated components included food waste (fruits, vegetables, leftover food, eggshells, dairy products), paper waste (packaging cardboard, newspapers, magazines, tissue paper, tetra packs), plastic waste (bottles, packaging, bags, lids, plastic cutlery, toys, gift wraps), glass waste (bottles, jars, broken glassware, light bulbs, colored glass), metal waste (cans, foil, appliances), textiles waste (linens, towels, thread waste), rubber/ leather waste (shoes, bags) and others waste (batteries, ash, stone, rock, diapers, medicines, paint boxes).

\section{Per capita waste generation (PCG) computation}

PCG $(\mathrm{kg} /$ day $/$ person $)=\frac{\text { Waste generated per day }}{\text { Population }}$ 


\section{Waste Footprint computation}

Waste foot print is the measurement of biologically productive land required to assimilate the generated waste. It was calculated by following formula figured by (Habibi et al., $2015)^{[25]}$.

Waste footprint $(\mathrm{ha})=\frac{\text { Total amount of waste generated } \times 8 \mathrm{~m} 2 \times 450 \mathrm{~kg}}{1000 \mathrm{~m} 2}$

\section{Statistical Analysis}

The data derived from the experiment conducted was subjected to statistical analysis through Factorial Randomized Design (RBD) and the significance of each treatment was calculated (Cochran and Cox, 1964) ${ }^{[26]}$. For the sake of brevity the data of the years 2018 and 2019 was pooled and statistically analyzed. The projections of urban solid waste was estimated using SPSS v 20.0.

\section{Results and Discussion}

\section{Physical characterization of urban solid waste}

The physical characterization plays an important role in characterization of a waste stream, results of which indicate fraction of organics, inert and recyclables present in the urban solid waste which help in determining the treatment procedures for urban solid waste. The results of physical characterization of solid waste from different urban areas are presented in Table 1. The maximum urban solid waste generation was discerned in Solan (19.527 t day ${ }^{-1}$ ) followed by Baddi (13.905 t day $\left.{ }^{-1}\right)$, Nalagarh (3.177 t day $\left.{ }^{-1}\right)$, Parwanoo $\left(2.682 \mathrm{t} \mathrm{day}^{-1}\right)$ and Arki $\left(0.896 \mathrm{t} \mathrm{day}^{-1}\right)$. The higher generation rate of urban solid waste in Solan may be imputed to more commercialization and development in the region. Keeping pace with the region's expansion and to meet modern day requirements of the burgeoning population, new commercial areas have also been added. Further it may be attributed to higher income and standards of life causing an increase in the consumption of goods and services, thereby resulting in increased proportions of disposable materials, especially packaging materials as reported by Medina M (2010) ${ }^{[27]}$ and Tsheleza et al., 2019) ${ }^{[28]}$. The study further indicated that food waste $\left(20.098 \mathrm{t} \mathrm{day}^{-1}\right)$ was the highest component generated followed by paper $\left(8.814 \mathrm{t} \mathrm{day}^{-1}\right)$, plastic $(7.404 \mathrm{t}$ day $\left.^{-1}\right)$, glass $\left(1.707 \mathrm{t} \mathrm{day}^{-1}\right)$, others $\left(0.845 \mathrm{t} \mathrm{day}^{-1}\right)$, metal $\left(0.480 \mathrm{t} \mathrm{day}^{-1}\right)$, textiles $\left(0.439 \mathrm{t} \mathrm{day}^{-1}\right)$ and rubber/ leather $\left(0.402 \mathrm{t} \mathrm{day}^{-1}\right)$. The results are in line with the findings of Visvanathan (2006) ${ }^{[29]}$ and Verma and Tripathi, $2016^{[30]}$ who reported that the fraction of food waste is quite high in Indian MSW, essentially due to the habit of using fresh vegetables as documented. The relatively high share of paper and plastic can be ascribed to the extensive use of paper packaging materials and as a result of high level of tourist activities.

Table 1: Physical composition of urban solid waste $\left(\mathrm{t} \mathrm{day}^{-1}\right)$

\begin{tabular}{|c|c|c|c|c|c|c|}
\hline Urban areas & Arki & Baddi & Nalagarh & Parwanoo & Solan & Total \\
\hline \multirow{2}{*}{ Components } & 0.467 & 7.023 & 1.610 & 1.350 & 9.648 & 20.098 \\
& $(52.06)$ & $(50.51)$ & $(50.68)$ & $(50.32)$ & $(49.41)$ & $(50.01)$ \\
\hline \multirow{2}{*}{ Paper } & 0.227 & 2.503 & 0.687 & 0.571 & 4.826 & 8.814 \\
& $(25.31)$ & $(18.00)$ & $(21.62)$ & $(21.28)$ & $(24.71)$ & $(21.93)$ \\
\hline \multirow{2}{*}{ Plastic } & 0.139 & 2.874 & 0.597 & 0.524 & 3.270 & 7.404 \\
& $(15.50)$ & $(20.67)$ & $(18.79)$ & $(19.53)$ & $(16.75)$ & $(18.42)$ \\
\hline \multirow{2}{*}{ Glass } & 0.023 & 0.623 & 0.133 & 0.097 & 0.831 & 1.707 \\
& $(2.56)$ & $(4.48)$ & $(4.19)$ & $(3.62)$ & $(4.26)$ & $(4.25)$ \\
\hline \multirow{2}{*}{ Metal } & 0.009 & 0.211 & 0.040 & 0.030 & 0.190 & 0.480 \\
& $(1.00)$ & $(1.52)$ & $(1.26)$ & $(1.12)$ & $(0.97)$ & $(1.19)$ \\
\hline \multirow{2}{*}{ Textiles } & 0.008 & 0.121 & 0.033 & 0.026 & 0.251 & 0.439 \\
& $(0.89)$ & $(0.87)$ & $(1.04)$ & $(0.97)$ & $(1.29)$ & $(1.09)$ \\
\hline \multirow{2}{*}{ Others } & 0.018 & 0.392 & 0.052 & 0.058 & 0.325 & 0.845 \\
& $(2.01)$ & $(2.82)$ & $(1.64)$ & $(2.16)$ & $(1.66)$ & $(2.10)$ \\
\hline \multirow{2}{*}{ Rubber/Leather } & 0.006 & 0.157 & 0.025 & 0.027 & 0.187 & 0.402 \\
& $(0.67)$ & $(1.13)$ & $(0.79)$ & $(1.01)$ & $(0.96)$ & $(1.00)$ \\
\hline \multirow{2}{*}{ Total } & 0.896 & 13.905 & 3.177 & 2.682 & 19.527 & 40.187 \\
& $(100.00)$ & $(100.00)$ & $(100.00)$ & $(100.00)$ & $(100.00)$ & $(100.00)$ \\
\hline
\end{tabular}

(The values in parenthesis are in percent)

Among different urban areas food, paper, plastic, glass, metal, textiles, others, rubber / leather waste were found in the range of 0.467 to $9.648 \mathrm{t} \mathrm{day}^{-1}, 0.227$ to $4.826 \mathrm{t} \mathrm{day}^{-1}, 0.139$ to 3.270 t day ${ }^{-1}, 0.023$ to $0.831 \mathrm{t} \mathrm{day}^{-1}, 0.009$ to $0.211 \mathrm{t} \mathrm{day}^{-1}, 0.008$ to $0.251 \mathrm{t} \mathrm{day}^{-1}, 0.018$ to $0.392 \mathrm{t} \mathrm{day}^{-1}, 0.006$ to $0.187 \mathrm{t} \mathrm{day}^{-1}$. The organic waste represented the largest percentage of the total solid waste generated in different urban areas and followed the order: Arki $(52.06 \%)>$ Nalagarh $(50.68 \%)>$ Baddi $(50.51 \%)>$ Parwanoo $(50.32 \%)>$ Solan $(49.41 \%)$ as detailed in Table 1. The results are conformity with the findings of Goel S (2008) ${ }^{[31]}$ and Sharholy et al., $2008{ }^{\text {[32] }}$ who reported that with decrease in socio-economic status on area, organic fraction of the waste increases. Waste generation rates for different urban areas varied from 0.217 to $0.408 \mathrm{~kg}$ capita $^{-1}$ day $^{-1}$ (Table 2). It was perceived to be maximum in Solan $\left(0.408 \mathrm{~kg}\right.$ capita $^{-1}$ day $\left.^{-1}\right)$ followed by Baddi $(0.368 \mathrm{~kg}$ capita $^{-1}$ day $\left.^{-1}\right)$, Nalagarh $\left(0.254 \mathrm{~kg}_{\text {capita }}{ }^{-1}\right.$ day $\left.^{-1}\right)$, Parwanoo $\left(0.248 \mathrm{~kg} \mathrm{capita}^{-1}\right.$ day $\left.^{-1}\right)$ and Arki $\left(0.217 \mathrm{~kg} \mathrm{capita}^{-1}\right.$ day $\left.^{-1}\right)$.

Table 2: Waste generation rates of urban areas of Solan District

\begin{tabular}{|c|c|}
\hline Urban areas & Generation rate $\left(\mathbf{k g ~ c a p i t a}^{\mathbf{- 1}}\right.$ day $\left.^{\mathbf{- 1}}\right)$ \\
\hline Arki & 0.217 \\
\hline Baddi & 0.368 \\
\hline Nalagarh & 0.254 \\
\hline Parwanoo & 0.248 \\
\hline Solan & 0.408 \\
\hline \multicolumn{2}{|c}{} \\
\hline
\end{tabular}




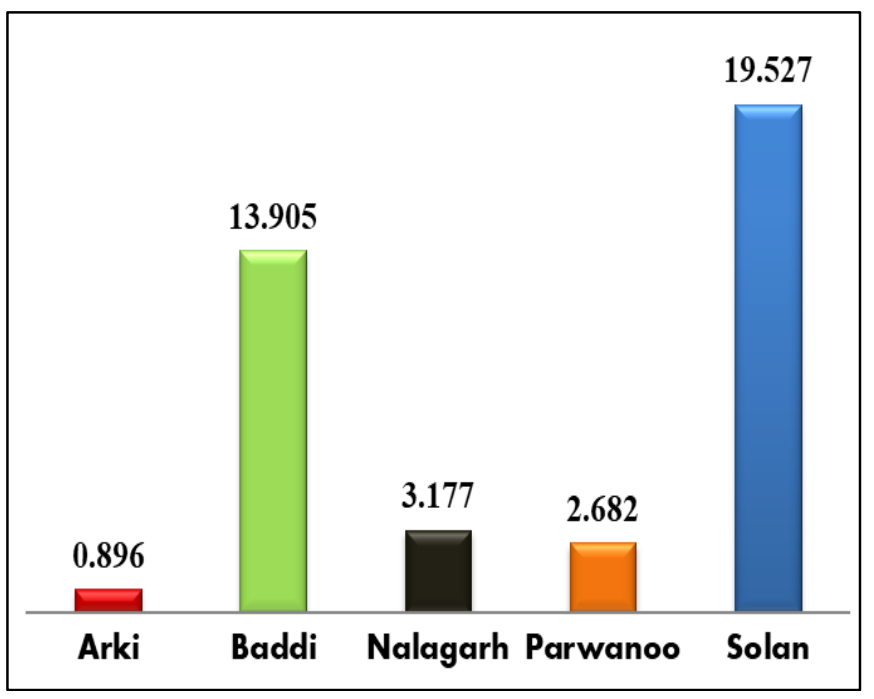

Fig 2: Total solid waste generated in urban areas $\left(t_{\text {day }}{ }^{-1}\right)$

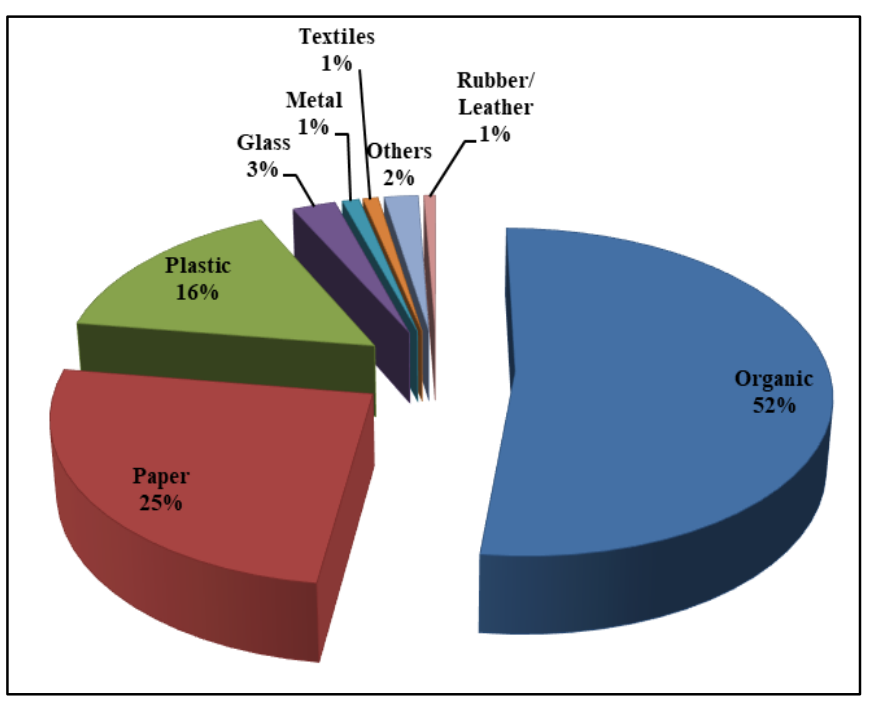

Fig 3: Arki solid waste characterization in percent

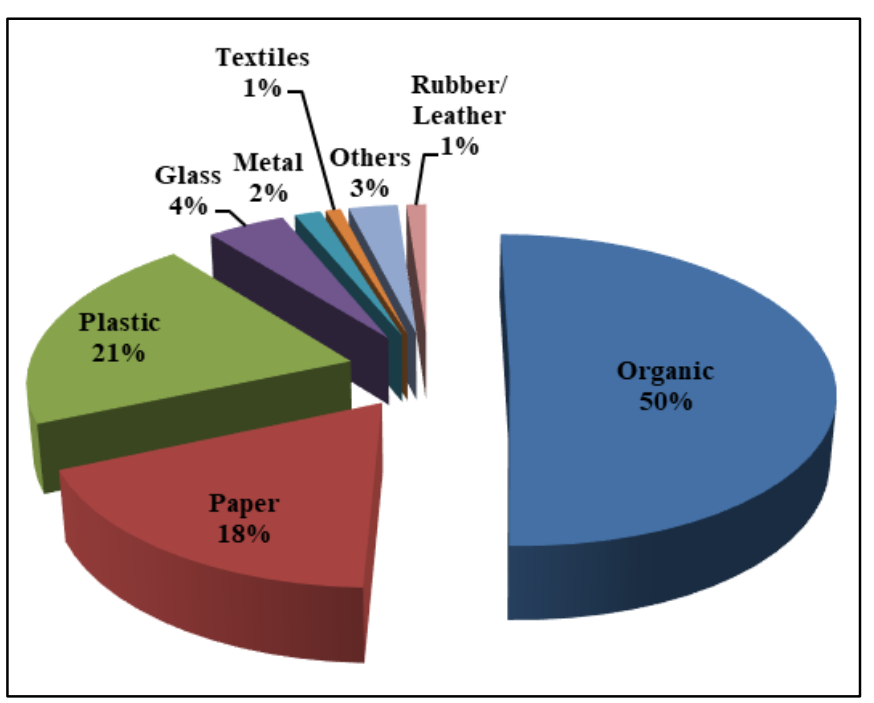

Fig 4: Baddi solid waste characterization in percent

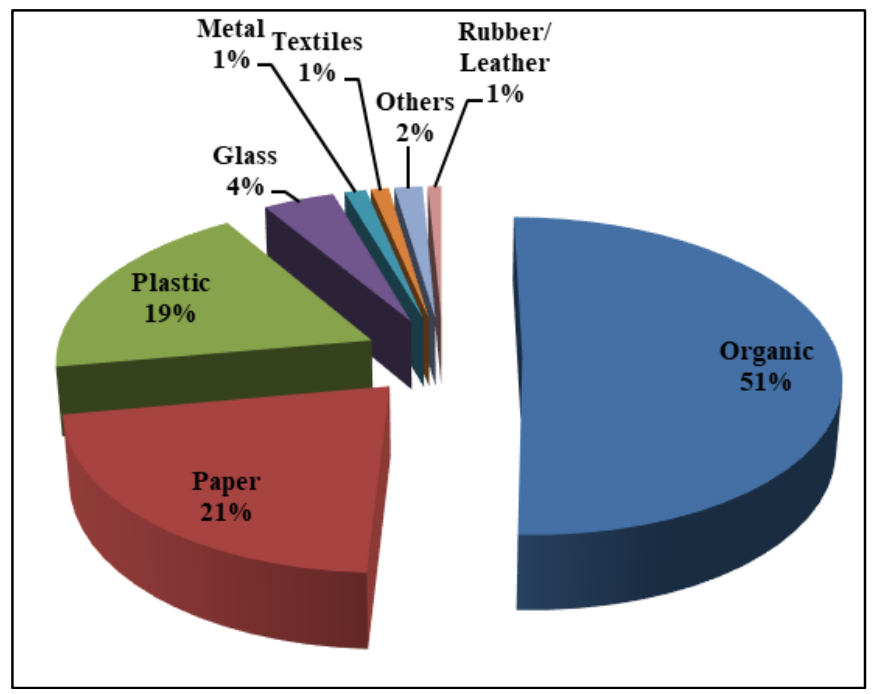

Fig 5: Nalagarh solid waste characterization in percent

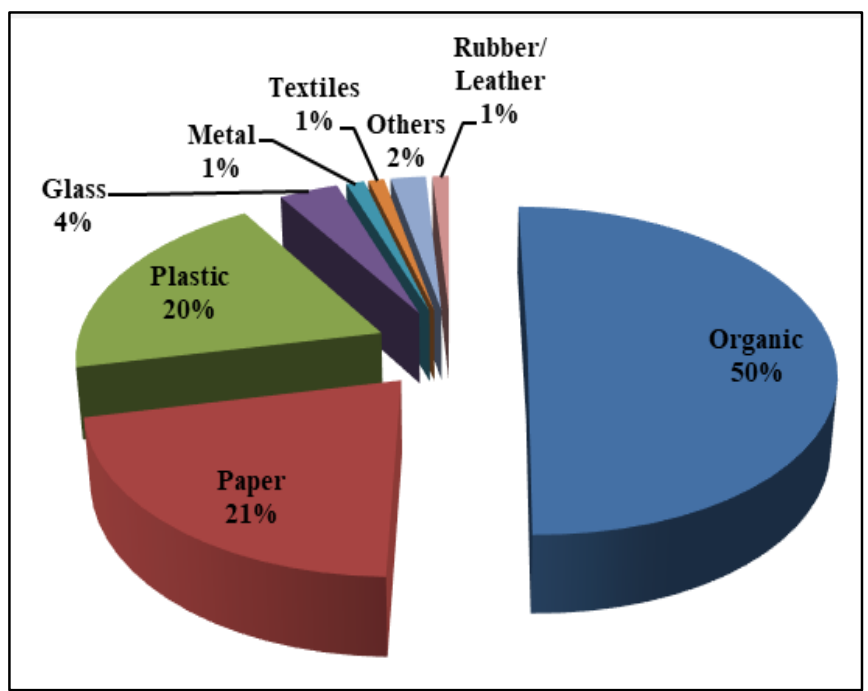

Fig 6: Parwanoo solid waste characterization in percent

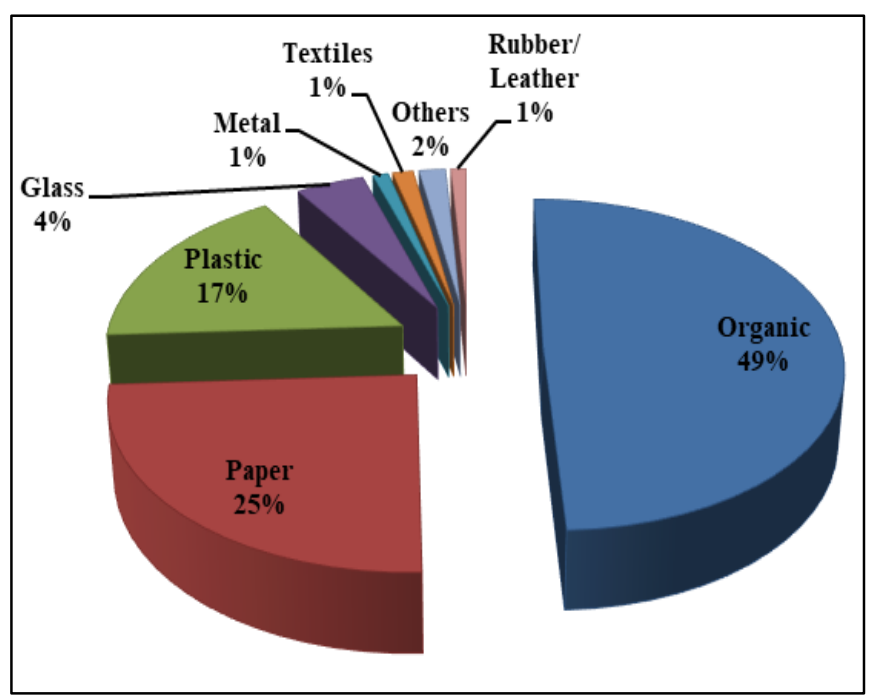

Fig 7: Solan solid waste characterization in percent Projections of urban solid waste generation 
In urban areas of Solan District solid waste generation exhibited significant increase during almost two decades, from 2001 to 2019. It is evident from the figures (8-12) that waste generation in Arki, Baddi, Nalagarh, Parwanoo and Solan increased from 0.57 to $0.90 \mathrm{t} \mathrm{day}^{-1}, 8.32$ to $13.91 \mathrm{t} \mathrm{day}^{-}$ ${ }^{1}, 2.20$ to $3.18 \mathrm{t} \mathrm{day}^{-1}, 1.41$ to $2.68 \mathrm{t} \mathrm{day}^{-1}$ and 10.06 to $19.53 \mathrm{t}$ day $^{-1}$ during 2001 to 2019 respectively. It is perceptible from the figures $(8-12)$ that by 2025 the urban solid waste generation would be $0.94 \mathrm{t} \mathrm{day}^{-1}, 16.33 \mathrm{t} \mathrm{day}^{-1}, 3.40 \mathrm{t} \mathrm{day}^{-1}$,
3.26 t day $^{-1}, 23.92 \mathrm{t} \mathrm{day}^{-1}$ for Arki, Baddi, Nalagarh, Parwanoo and Solan respectively. Similar trends in urban solid waste generation have also been reported by PIB ${ }^{[33]}$ in urban areas of our country. If the rate of urban solid waste generation continues at the same rate, then the annual land requirement for disposal of waste by 2025 would be 0.61 ha, 10.60 ha, 2.21 ha, 2.12 ha, 15.52 ha for Arki, Baddi, Nalagarh, Parwanoo and Solan respectively.

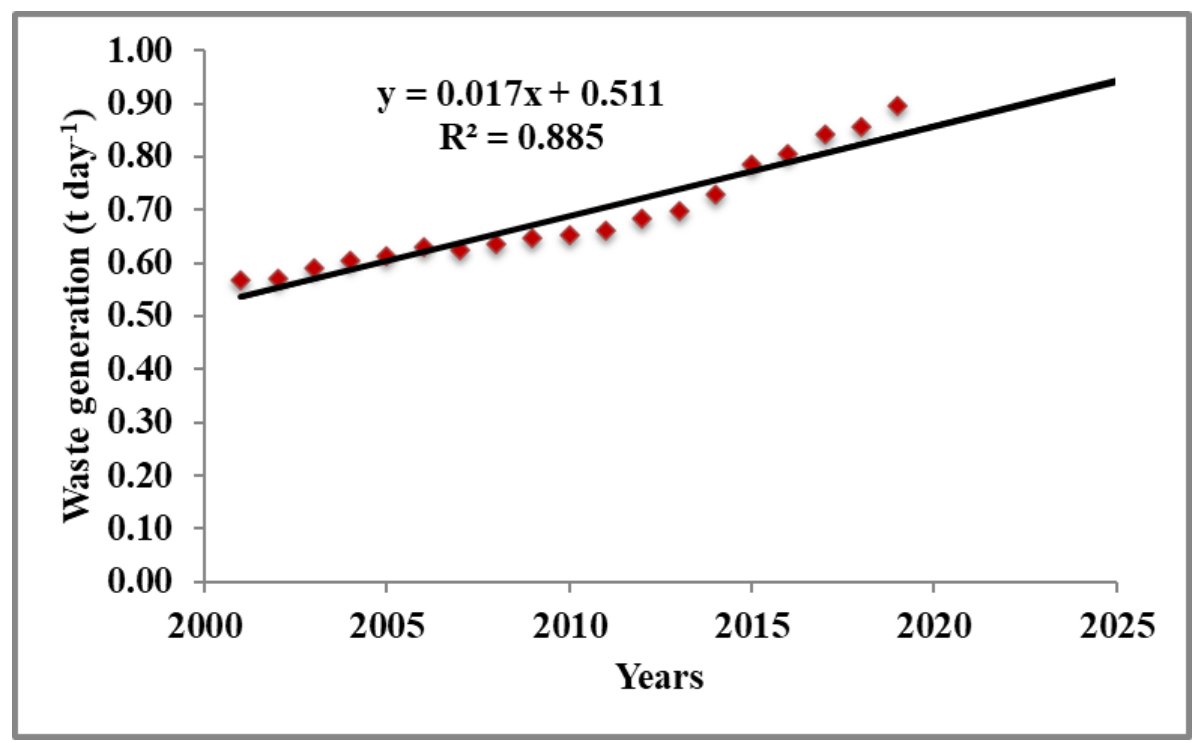

Fig 8: Periodic trend in urban solid waste generation in Arki

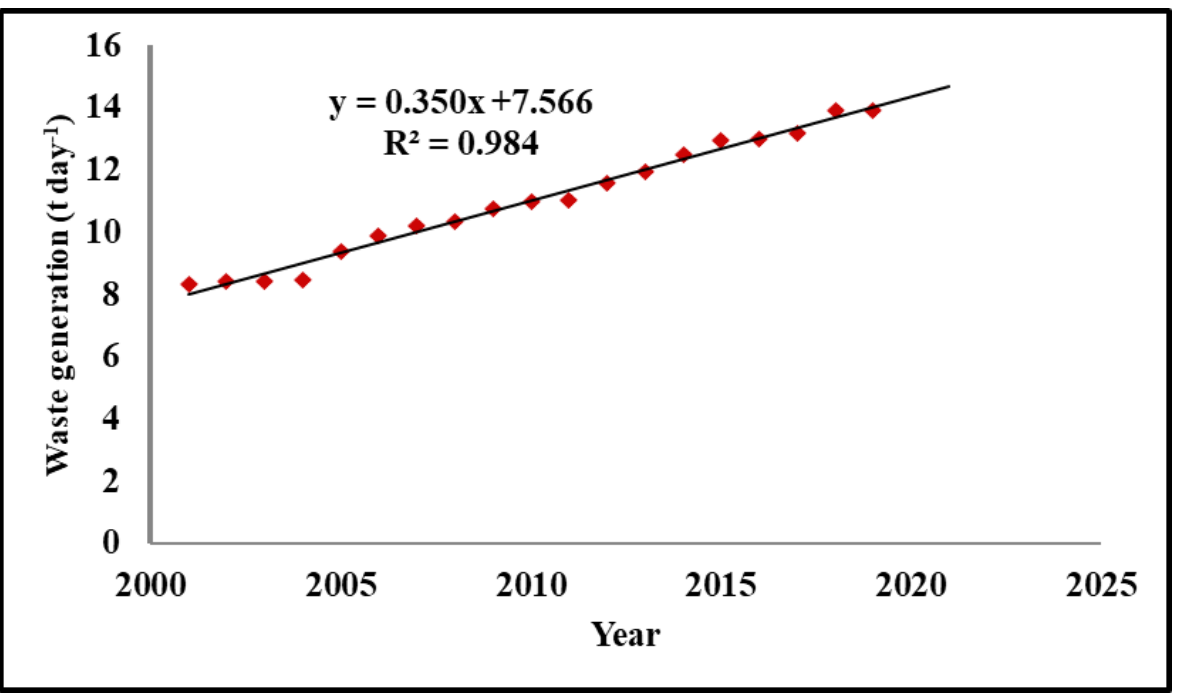

Fig 9: Periodic trend in urban solid waste generation in Baddi 


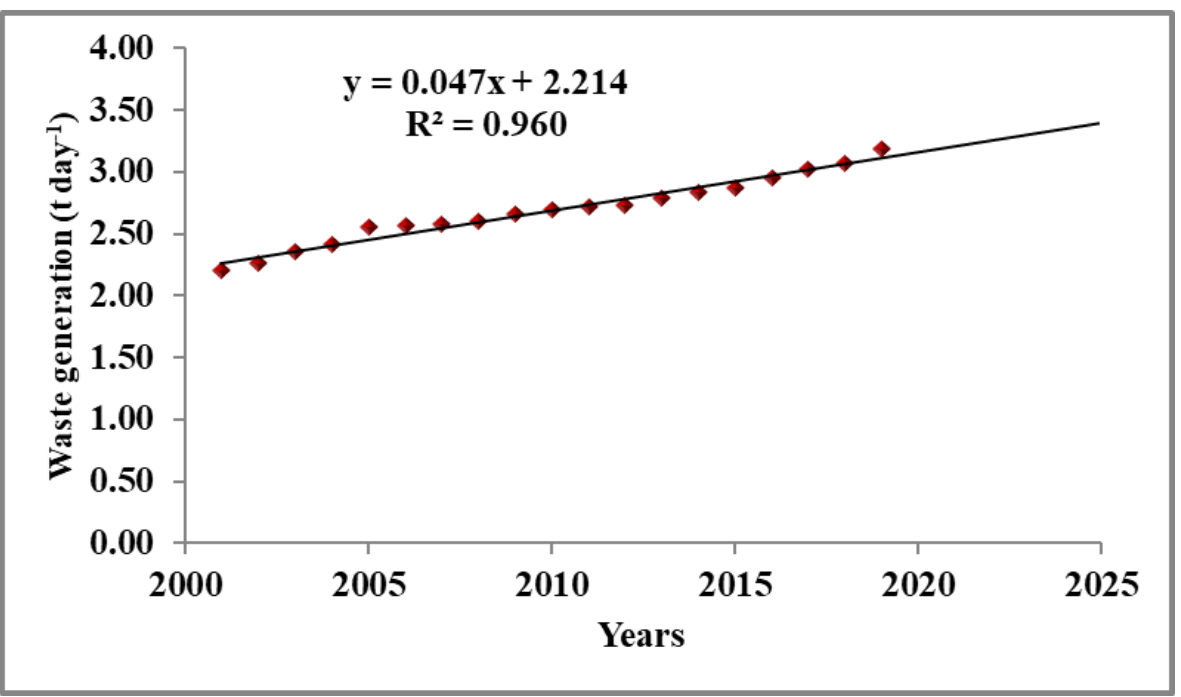

Fig 10: Periodic trend in urban solid waste generation in Nalagarh

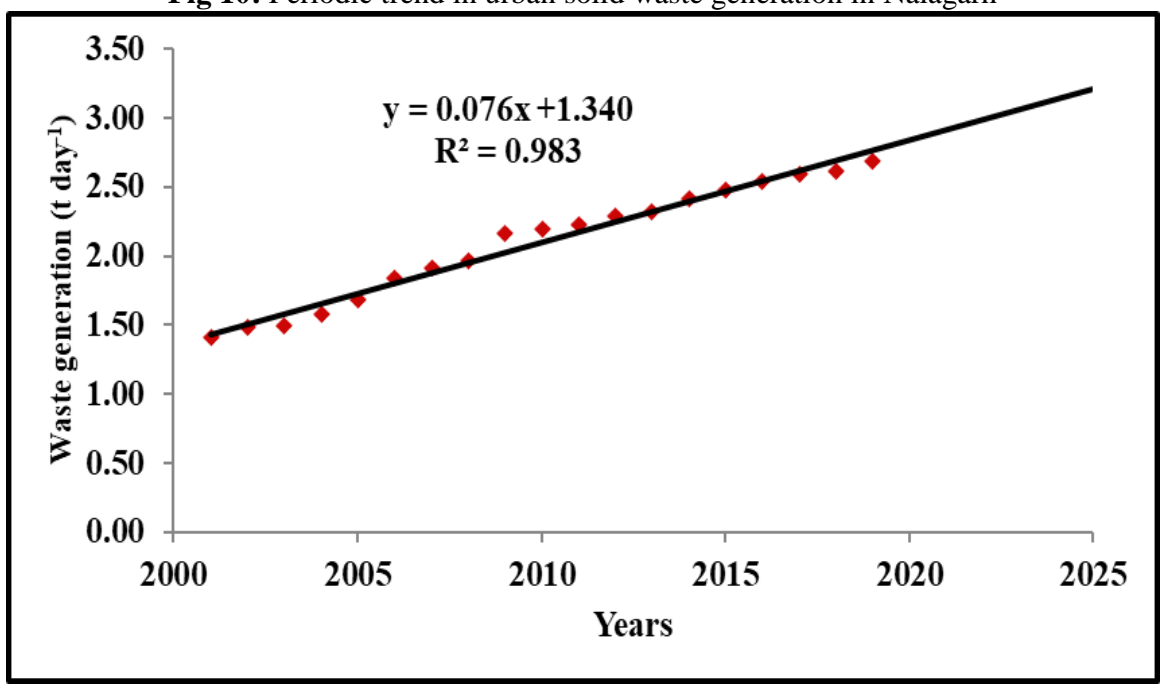

Fig 11: Periodic trend in urban solid waste generation in Parwanoo

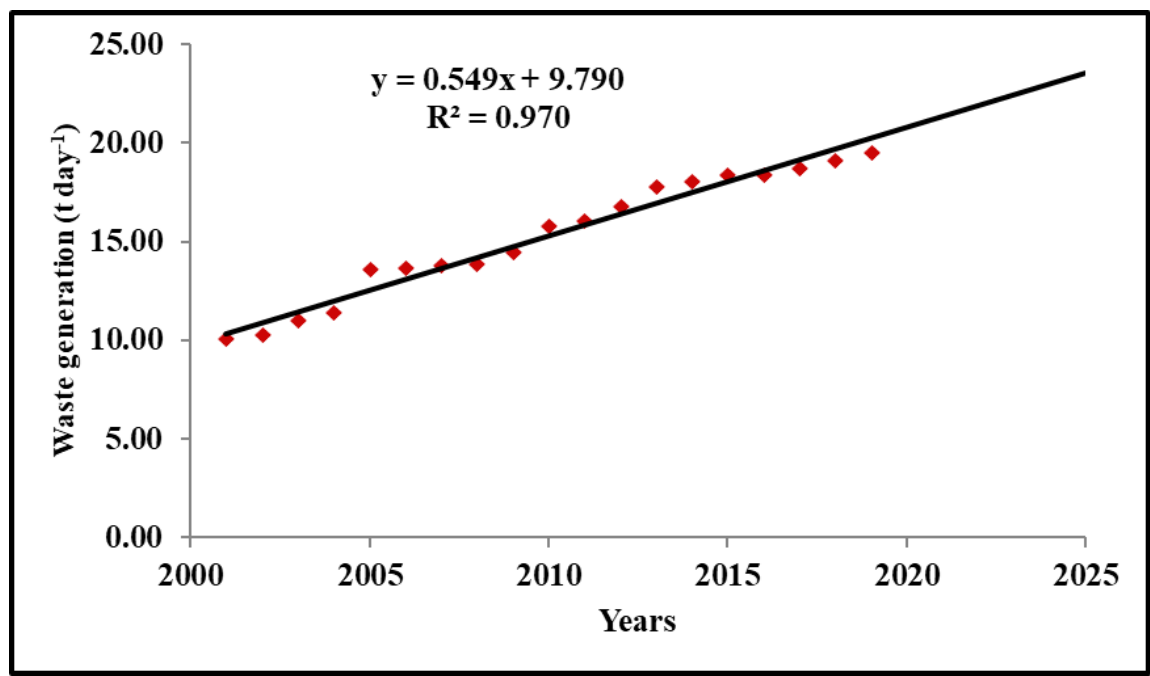

Fig 12: Periodic trend in urban solid waste generation in Solan 


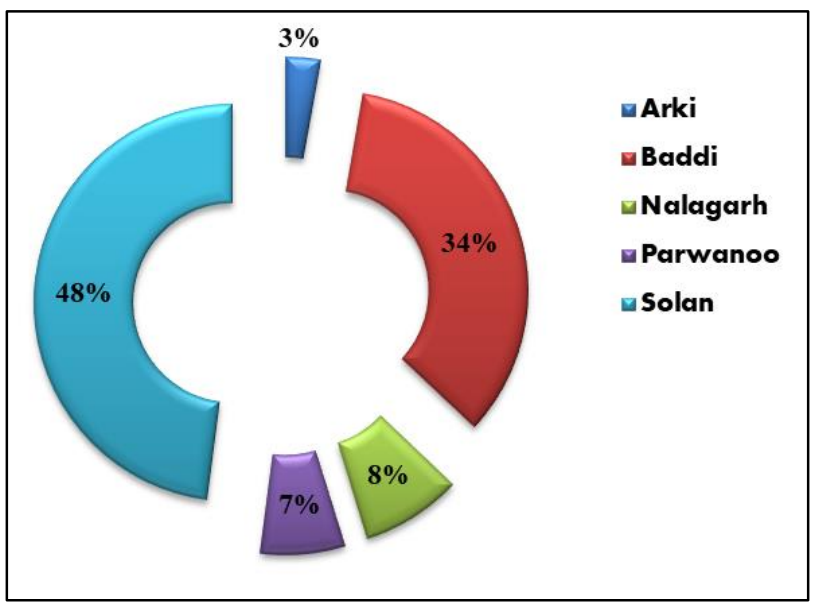

Fig 13: Relative percent contribution in waste footprint by different urban areas

\section{Waste footprint}

The perusal of the data presented in Table 5 indicated that the waste footprint of different urban areas ranged from 0.002 to 0.035 ha. It was perceived to be maximum in Solan $(0.035$ ha $)$ followed by Baddi (0.025 gha), Nalagarh (0.006 ha), Parwanoo (0.005 ha) and Arki (0.002 ha). The maximum waste footprint of Solan may be attributed to maximum waste generation in the region, due to increased households and income, changing life style of the people, high standard of living of the people and consumption expenditure. Arunachalam (2010) ${ }^{[34]}$ supported the view that the explosion of population coupled with rapid urbanization and increasing number of households are resulting in increasing solid waste generation. The western consumerism, demonstration effects, changed life style of present society into "Throw away society", changing habit of the people to buy unnecessary goods, improvement in package or polythene coverage etc have resulted in more solid waste generation by the sample households Abduli MA (2007) ${ }^{[35]}$.

Table 3: Waste footprint (ha) of urban areas of Solan

\begin{tabular}{|c|c|c|}
\hline Seasons & Waste Footprint & Percent \\
\hline Arban areas & 0.002 & 2.74 \\
\hline Baddi & 0.025 & 34.25 \\
\hline Nalagarh & 0.006 & 8.22 \\
\hline Parwanoo & 0.005 & 6.85 \\
\hline Solan & 0.035 & 47.95 \\
\hline Total & 0.073 & \\
\hline
\end{tabular}

\section{Conclusion}

The study deduced that urbanization in district Solan of Himachal Pradesh had enhanced waste generation and footprint of the region. It was observed that the economic activities and the lifestyle of the population determine the characteristics of the generated waste; therefore they vary depending on the area where the samples were taken as well as on the season. The higher proportion of organic waste in this region indicated towards it potential for biorecycling, biogas production and biofuels. Also, this characterization can be considered as reference for choosing the possible treatment process, so that methods such as composting - agricultural recovery, biodegradation in reactors - energetic recovery, the recycling of metals and glass or other recyclable materials (paper, cardboard, plastic) - economic recovery, etc. could be optimized. The present rate of urban solid waste to the tune of $3.01 \%$ annually demands 0.58 ha, 9.02 ha, 2.06 ha, 1.74 ha,
12.67 ha land for Arki, Baddi, Nalagarh, Parwanoo and Solan respectively, which is further projected to increase to 0.61 ha, 10.60 ha, 2.21 ha, 2.12 ha, 15.52 ha for Arki, Baddi, Nalagarh, Parwanoo and Solan during 2025 which may lead to unsustainability. Therefore, to sustain urbanization in the district, thrust to the development of smart cities should be given by going along the route of urban renewal and adoption of environment friendly measures. Thus if urban solid waste is managed in an appropriate manner then it not only mitigates the negative effects but it could help in meeting the demand of ecology and economy.

\section{Acknowledgment}

The facilities provided by the Department of Environment Science, YSP University of Horticulture \& Forestry, Nauni, Solan (HP) India are highly acknowledged.

\section{Conflict of Interest}

There is no conflict of interest for this manuscript.

\section{Reference}

1. USEPA Solid Waste Management: A Local Challenge with Global Impacts; United States Environmental Protection Agency: Washington, DC, USA,2002.

2. Karak T, Bhagat RM, Bhattacharyya P. Municipal Solid Waste Generation, Composition and Management: The World Scenario. Critical Reviews in Environmental Science and Technology. 2012; 42:1509-1630

3. Palanivel TM, Sulaiman H. Generation and Composition of Municipal Solid Waste (MSW) in Muscat, Sultanate of Oman. APCBEE Procedia. 2014; 10:96-102

4. Hoornweg D, Bhada-Tata P, Kennedy C. Environment: Waste production must peak this century. Nature. 2013; 50(2):74-73

5. Solberg E. A Study on the Opportunities in a New Solid Waste Management in Iringa Municipality. M.Sc. Thesis. University College of Oslo and Akershus, Oslo, Norway. 2012, 78

6. Nabegu AB. An analysis of municipal solid waste in Kano metropolis, Nigeria. Journal of Human Ecology. 2010; 31(2):111-119

7. Valkenburg C, Walton CW, Thompson BL, Gerber MA, Jones S, Stevens DJ. Municipal solid waste to liquid fuels synthesis, Volume 1: Availability of feedstock and Technol. PNNL 18144, Pacific Northwest National Laboratory, Richland, WA, 2008.

8. Yukalang N, Clarke B, Ross K. Solid Waste Management Solutions for a Rapidly Urbanizing Area in Thailand: Recommendations Based on Stakeholder Input. International Journal of Environmental Research and Public Health. 2018 15(1):1302-1325.

9. Delgado OB, Rodriguez JMO, Clemitshaw KC, Razo $\mathrm{CG}$, Paniagua IYH. Use of genetic algorithms to improve the solid waste collection service in an urban area. Waste Management. 2015; 4(1):20-27

10. Khaiwal R, Kaur K, Mor S. SWOT analysis of waste management practices in Chandigarh, India and prospects for sustainable cities. Journal of Environmental Biology 2015; 37(1):327-332.

11. Gutberlet J. Waste in the city: Challenges and opportunities for urban agglomerations, urban agglomeration Mustafa Ergen', Intech. 2018. https://www.intechopen.com/books/urban-agglomeration/ waste-in-the-city-challenges-and-opportunities-for-urbanagglomerations 
12. Okot-Okumu J. Solid waste management in African cities - East Africa, 2012. https://www.intechopen. com/books/waste-management-an-integrated-

vision/solid-waste-management-in-african-cities-eastafrica.

13. Mohammed A, Elias E. Domestic solid waste management and its environmental impacts in Addis Ababa city. Journal of Environment and Waste Management. 2017; 4(1):194-203.

14. Yadav S. Environmental pollution effects on living beings. International Journal of Scientific Research in Science and Technology. 2018; 4(7):143-150.

15. Thanh NP, Matsui Y, Fujiwara T. Household solid waste generation and characteristic in a Mekong Delta city, Vietnam. Journal of Environmental Management. 2010; 91(11):2307-2321.

16. Aslani H, Taghipour H. Seasonal characterization and quantification of municipal solid waste: Energy content and statistical analysis. Journal of Advanced Environmental Health Research. 2018; 6(1):34-43

17. Marshall E, Farahbakhsh K. Systems approaches to integrated solid waste management in developing countries. Waste Management. 2013; 33:988-1003.

18. Schubeler P. Urban. Management and Infrastructure, Conceptual Framework for Municipal Solid Waste Management in Low-Income Countries; Working Paper No. 9; UNDP/UNCHS (Habitat)/World Bank/SDC Collaborative Programme: St. Gallen, Switzerland. 1996, 59

19. Mir MA, Ghazvinei PT, Sulaimana NMN, Basrid NEA, Saherid S, Mahmoode NZ, Jahanf A, Begumg RA et al. Application of TOPSIS and VIKOR improved versions in a multi criteria decision analysis to develop an optimized municipal solid waste management model. Journal of Environment Management. 2016; 16(6):109-115.

20. Puthillath B, Sasikumar R. Integrated Solid Waste Management Score Board-A tool to measure performance in Municipal Solid Waste Management. International Journal of Emerging Trends \& Technology in Computer Science. 2015; 4(5):109-114

21. Varma RA. Status of municipal solid waste generation in Kerala and their characteristics.

<http://www.sanitation.kerala.gov.in, 2015

22. Wackernagel M, Kitzes J, Moran D, Goldfinger S, Thomas M. The ecological footprint of cities and regions: comparing resource availability with resource demand. Environment and Urbanization. 2006; 18:103-112

23. Salequzzaman MD, Sultana UT, Iqbal, Hoque A. Ecological footprint of waste generation as a sustainable tool for solid waste management in the Khulna City Corporation of Bangladesh. In: Proceedings of International Conference on Complex Systems. Marriott Boston Quincy, Boston, USA. 2006, 1-12

24. Ravi A, Vishudas S, Kumar CEA. Waste footprint of Kochi city, Kerala, India - a statistical analysis. Global journal for research analysis. 2017; 6(4):644-647.

25. Habibi K, Rahimi A, Shahmoradi B, Abdi H. Analysis of ecological footprint at educational institute scale (A case of an Iranian high school). Advances in Research. 2015 4(2):114-121.

26. Cochran GC, Cox GM. Experimental Designs. Asia Publishing House, Bombay. 1964, 611

27. Medina M. Brazil: The world's largest and most dynamic scavenger movement. Bio Cycle. 2010; 51(10):32-33.
28. Tsheleza V, Ndhleve S, Kabiti HM, Musampa CM, Nakin MDV. Vulnerability of growing cities to solid waste-related environmental hazards: The case of Mthatha, South Africa, Jàmbá: Journal of Disaster Risk Studies. 2019; 11(1):632-642.

29. Visvanathan C. Solid Waste Management in Asian Perspectives. Asian Institute of Technology, Bangkok. 2006, 1-7

30. Verma N, Tripathi AK. Municipal Solid Waste composition, quantification and characterization at the three MSW dumping Sites of Himachal Pradesh: A case Study. Indian Journal of Forestry. 2016; 39(1):31-36.

31. Goel S. Municipal Solid Waste Management in India a critical review. Journal of Environmental Science and Engineering Technology. 2008; 50(4):319-328

32. Sharholy M, Ahmad K, Mahmood G, Trivedi RC. Municipal Solid Waste Management in Indian cities- A review. Waste Management. 2008; 28:459-467.

33. PIB. Solid Waste Management Rules revised after 16 years; rules now extend to urban and industrial areas. Press Information Bureau, Government of India, 2016.

34. Arunachalam G. Generation and Management of Household Municipal solid wastes in extension and town areas of Tiruvarur, Tamilnadu, Southern India. Scientific Transactions in Environment and Technovation. 2010; 3(1):135-137

35. Abduli MA. Islamic Republic of Iran. In: Solid Waste Management: Issues and Challenges in Asia. Asian Productivity Organization, Tokyo, 2007, 92-117. 